\title{
第三紀層地帯におけるDEM地形解析による地すべり地形斜面の最頻傾斜角

\author{
The most frequent angle of landslide in Tertiary formation based on \\ DEM topographical analysis
}

\author{
長嶺元二 ${ }^{\mathrm{a})}$ *，大坂伊作 ${ }^{\mathrm{b})}$ ，鈴木素之 ${ }^{\mathrm{c})}$ ，山本哲朗 ${ }^{\mathrm{d})}$ \\ Genji NAGAMINE, Isaku OSAKA, Motoyuki SUZUKI and Tetsuro YAMAMOTO
}

\begin{abstract}
Focusing on the most frequent angle of landslide slope, in this study we examined the engineering features of Tertiary formations along the Japan Sea in the eastern part of Shimane prefecture, based on 50-m DEM (Digital Elevation Model) topographical analysis. Our main conclusions are summarized as follows : (1) In the study area, the distribution and angles of slopes composed of stratum in the Iwami and Izumo groups can be affected by the direction of the slope. However, the most frequent angle of the slopes is not related to the slope direction. (2) The most frequent angle of landslide slopes is very similar to that of natural slope. (3) The most frequent angle of landslide slopes tends to decrease with an increase in stratum order. (4) For the stratum of the Iwami groups, the landslide slopes were distributed more often in the areas in which small slope angles were more prevalent. The most frequent angle of the landslide slope showed a particular value that was dependent on the kind of stratum. Therefore, the most frequent angle of the landslide slope can be a useful index for estimating the strength parameter of a landslide's slip surface. Key words : DEM topographical analysis, landslide slope, most frequent angle, Tertiary formation, engineering features

\section{和文要旨}

本研究はDEM地形解析結果にもとづく地形指標のうち地すべり地形斜面の最頻傾斜角に着目し，その工学的特性を把握すること

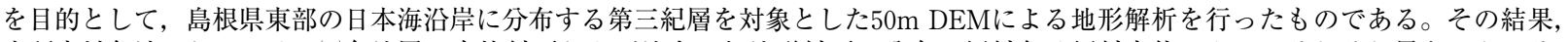
本研究対象域においては，(1)各地層の自然斜面および地すべり地形斜面の分布や傾斜角は傾斜方位によってそれぞれ異なるが，そ れらの最頻傾斜角の大きさには傾斜方位による違いが認められない, (2)地すべり地形斜面の最頻傾斜角は自然斜面の最頻傾斜角と ほぼ等しい，(3)地すべり地形斜面の最頻傾斜角は層序が上位になるに従って小さくなる傾向を示す，(4)石見層群の各地層では，地 すべり地形斜面の最頻傾斜角が小さいほど地すべり地形の分布が多いことを明らかにした。地すべり地形斜面の最頻傾斜角は地層 ごとに違いがあり，それは地すべり面のせん断抵抗角の推定等において参考にできる。

キーワード：DEM地形解析, 地すべり地形斜面, 最頻傾斜角, 第三紀層, 工学的特性
\end{abstract}

\section{1.はじめに}

DEM地形解析により求められる種々の地形指標を用 い，今般多くの研究が行われている。その現状は太田 （2006）によってまとめられているとおりであり，自然 災害に関する研究では斜面災害に対する各種地形指標の 寄与度の評価等が行われている（たとえば岩橋ら, 2008）。 しかし，地形指標を斜面強度の評価に関連づけるような 工学的活用を図ることを目的とした研究はこれまで進ん でいない。

筆者らは地すべり地形の斜面勾配が工学的に有意な地 形指標となる可能性を考えている。それは，高速道路調 査会（1985）や吉松ら（1991）が全国から収集した地す ベり事例を分析した結果に基づき，地すべり面のせん断 抵抗角が地すべり斜面の勾配と強い相関があることを明 らかにしていることを根拠にしており，地すべり地形の 斜面勾配が地すべり面のせん断抵抗角を推定する指標と なる可能性をもつと考えられるからである。これに関し

* 連絡著者/corresponding author

a ）財団法人道路保全技術センター

Road Management Technology Center

于730-0012 広島市中区上八丁堀 7 -

7-1, Kamihachoubori, Naka-Ward, Hiroshima-City, 730-0012. Japan

b ) イズテック株式会社

Izutec Co., LTD

Izutec Co., LTD
山口大学評価室

University Evaluation Department, Yamaguchi University

d) 山口大学大学院理工学研究科

Graduate School of Science and Engineering, Yamaguchi University
て筆者ら（2009）は，山口県下の三郡変成岩類を対象と して50m DEMを用いた地形解析を行い，地すべり地形 斜面の最頻傾斜角が風化土水浸試料の一面せん断試験に より求めたせん断抵抗角とほぼ等しいことを明らかにし ている。

本研究はDEM地形解析にもとづく地形指標のうち地 すべり地形斜面の最頻傾斜角に着目し，その工学的特性 を把握することを目的として，島根県東部の日本海沿岸 に分布する第三紀層を対象とした $50 \mathrm{~m} \mathrm{DEM}$ 地形解析を 行ったものである。なお，地形解析を行うにあたっては 対象とする地山岩盤の不均質性を避けるため，対象を第 三紀層よりなる軟岩地山とした。また，地すべり地形は 同一の地層内に分布するものであっても風化の程度の違 いに原因する不均質性を有するため，その影響が小さく なるように広域に分布する地層を対象とした。さらに， 解析に用いるDEMのメッシュ間隔は小さいほど詳細な 地形の起伏が計測されて精度が向上するものの, 細密に 過ぎると大局を見失うため，本研究では後述するように 幅が $100 \mathrm{~m}$ 程度よりも規模の大きい地すべりを対象とす ることから，国土地理院により全国的に整備されている 50m DEMを用いた。 


\section{2. データの取得と傾斜角および傾斜方位の算定}

\section{1 数值地図}

地形情報は国土地理院発行 (2000) の数值地図50mメッ

シュ（標高）を用いた。傾斜角 $S$ および傾斜方位 $A s$ の 算定は沖村ほか（1991）や神谷ほか（2000）に従い計算 式(1)〜(4)により行った。

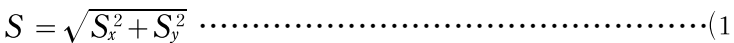

$$
\begin{aligned}
& A_{s}=\tan ^{-1}\left(S_{y} / S_{x}\right) \\
& S_{x}=\frac{\left(H_{11}+H_{21}+H_{31}\right)-\left(H_{13}+H_{23}+H_{33}\right)}{6 D_{x}} \\
& S_{y}=\frac{\left(H_{11}+H_{12}+H_{13}\right)-\left(H_{31}+H_{32}+H_{33}\right)}{6 D_{y}}
\end{aligned}
$$

ここで，Sは傾斜角， $A_{s}$ は傾斜方位， $S_{x}$ および $S_{y}$ はそ れぞれX方向およびY方向の傾斜， $D_{x}$ および゙ $D_{y}$ はそれぞ れX方向およびY方向の格子間距離である。図- 1 に模 式的に示すように，これらは対象メッシュを取り囲む 8 メッシュの標高デー夕を用いて算出され，最小二乗法で 求めた平面の最大傾斜に一致する。

\section{2 地質図}

地質情報は基本的に産業技術総合研究所発行の 5 万分 の 1 地質図幅を用いた。対象域は 5 万分の 1 図幅におい て「松江」(1994)，「今市」(1991)，「木次」(2005)，「大社」 （1989），「石見大田及び大浦」(1998)，「三瓶山」(1983）， 「温泉津及び江津」(2001)，「横田」，「頓原」の範囲にあ り，このうち「横田」については地質図幅の発行年が古 く第三紀層の地層区分が詳細になされていないため,「松 江」の解説書（1994）に示される約7.7万分の 1 図幅を 用いた。また地質図幅が未発行である「頓原」について は「木次」の解説書（2005）に示される約 6 万分の 1 図 幅を用いた。

\section{3 地すべり地形分布図}

地すべり地形情報は防災科学技術研究所発行の地す心゙ り地形分布図 $(2005,2006)$ を用いた。これは約 4 万分 の 1 空中写真判読により表層すべりを除き，地すべり， 地すべり性崩壊，大規模崩壊等が 5 万分の 1 地形図上に 描画されたものである。情報は滑落崖と移動体を一まと めにして取り込み，地すべり地形が複数の地層を横切る 場合には，それぞれについてデー夕取得領域(ポリゴン) を設定した。図ー2(a)，(b)にそれぞれ地すべり地形分布 図，傾斜角分布図の一例を示し，写真 -1 に図 $-2(\mathrm{a})$,

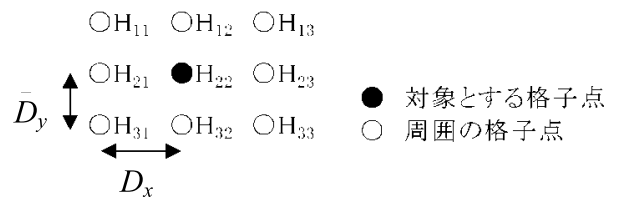

図一 1 傾斜量の計算に使用する格子点

Fig. 1 Grid Configuration for Calculating Angle and Direction of Slope

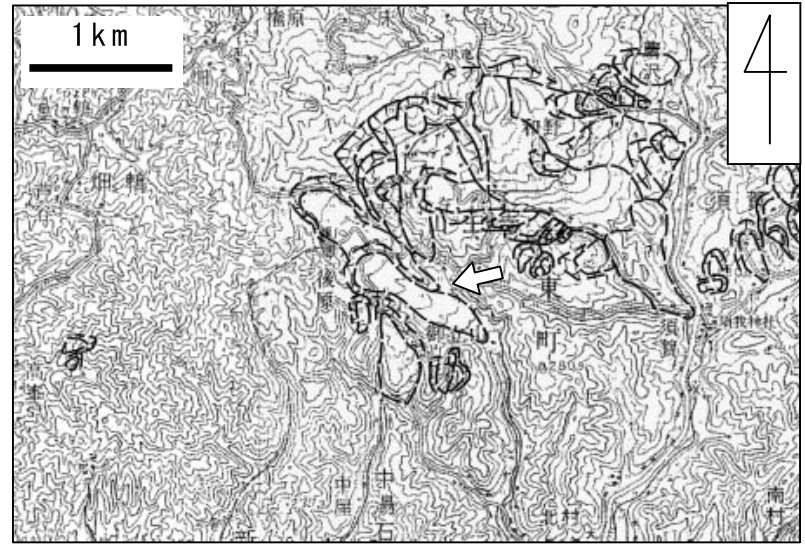

(a) 地すべり地形分布図

(国土地理院 5 万分の 1 地形図『松江』『今市』および防災科 学技術研究所地すべり地形分布図『松江』『今市』の一部を使用）

(a) Topographic Map of Landslide Area

(1 in 50,000 Scale Topographic Map of "Matsue" and "Imaichi" after Geographical Survey Institute of Japan incorporated with Landslide Map of "Matsue" and "Imaichi" after the National Research Institute for Earth Science and Disaster Prevention of Japan)

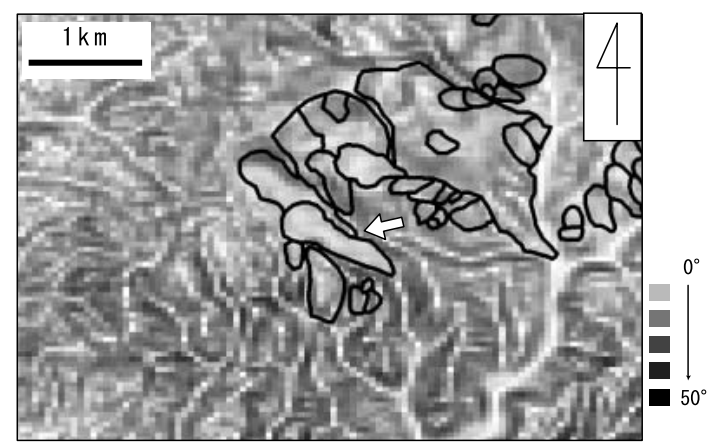

(b) 傾斜角分布図（モザイクの一つが50m格子）

(b) Slope Angles in $50 \mathrm{~m}$ Grids (One Piece of Mosaic shows $50 \mathrm{~m}$ grid)

図一２地すべり地形分布図と傾斜量図

Fig. 2 Topographic Map of Landslide Area and Slope Angles in 50m Grids

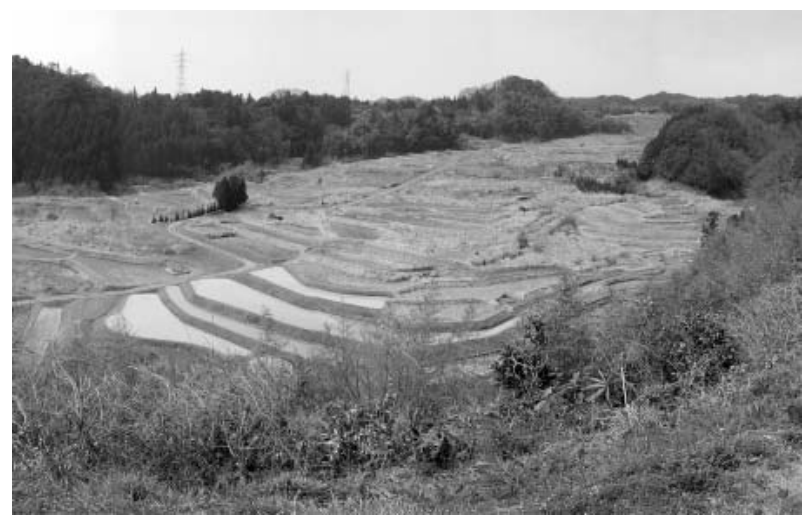

写真一 1 第三紀層地帯の地すべり 斜面（図一 2(a), (b)中の 矢印) (幅 $400 \mathrm{~m}$, 長さ $2,000 \mathrm{~m}$, 平均傾斜角 $8.5^{\circ}$ )

Photo. 1 Photograph of Landslide in Tertiary Formation (arrow shown in Figure $2(a)(b))(400 m$ wide, $2,000 \mathrm{~m}$ long, Average slope angle is $8.5 \mathrm{de}$ grees) 
(b)中に矢印で示した地すべり地形の状況を示す。

\section{3. 地質概要と地形解析結果}

\section{1 地質概要}

島根県東部の日本海沿岸はグリーンタフ変動による一 連の堆積物である中新統の第三紀層が分布し，地すべり の多発地帯となっている(図-3)。本研究で対象とす るのは島根半島を除く本土側の第三紀層であり，地層は 図 -4 に示すように下位から波多層，川合層，久利層， 大森層（これらを総称して石見層群）と，布志名層，松 江層（これらを総称して出雲層群）に区分されている（島 根県，1985)。最下層の波多層より上位の地層は日本海 側に向けて順に累重し，大略北に緩く傾斜する同斜構造 をなしており，参考にした地質図幅の解説書をもとに各 地層の性状を整理すれば表－1のようになる。

波多層は火山性陥没盆地に埋積した陸成火山岩層であ り，安山岩〜デイサイトの溶岩や火砕岩を主体とする。 川合層は波多層を不整合に覆う海成層であり，安山岩や デイサイトの水底溶岩火砕岩に碟岩・砂岩を挟む。久利 層は川合層と一部指交関係にある海成層であり，デイサ イトや流紋岩の水底溶岩火砕岩に泥岩を挟む。大森層は 久利層を不整合に覆う陸上ー浅海底に噴出した安山岩と デイサイトよりなり，浅海性の礫岩・砂岩に被覆される。 布志名層は碟岩から土丹状のシルト岩まで上方細粒化す る海成層である。松江層は布志名層に引き続く海成－汽 水成堆積物で，土工上は「土砂」に分類できるほど固結 度の低い砂岩よりなる。

\section{2 地形の特徵}

図 - 5 に自然斜面および地すべり地形斜面の傾斜角の 頻度分布を示す。また，表 -2 にメッシュ数の百分率か ら求めた各層の自然斜面と地すべり地形斜面の面積割合 および最頻傾斜角を示す。ここで，自然斜面は沖積平野 や谷底低地および河道を除き，地すべり地形斜面を含む 全ての斜面を対象としている。自然斜面の面積割合は, 対象とする全域の自然斜面の面積に対するその地層が占 める自然斜面の面積の比，すなわち構成割合である。地 すべり地形斜面の面積割合は，その地層の自然斜面の面 積に対する地すべり地形斜面の面積の比である。最頻傾 斜角は頻度分布を曲線近似した際のピークの傾斜角であ る。図一 5 および表一 2 によると, 自然斜面および地す ベり地形斜面の分布や傾斜角は，地層ごとに特徴をもっ て異なることがわかる。石見層群では，地すべり地形の 分布が火砕岩 $(4.2 \sim 9.1 \%)$ に比べて堆積岩（9.7〜 15.5\%）の方が多く，モンモリロナイトを多く含有する 久利層泥岩（三浦, 1982）で分布割合が最も大きい。地 すべり地形は幅が $500 \mathrm{~m}$ 以上もあ巨大なものも点在す る。これに対して出雲層群では, 自然斜面の傾斜角が石 見層群に比べて明らかに小さく，地すべり地形の分布も 少ない。地すべり地形は石見層群とは対照的に，いずれ も幅が $100 \mathrm{~m}$ 程度の小規模なものである。布志名層泥岩
は軟弱な粘土薄層を挟み，試験切土を行ったところ非常 に崩壊性が強い（中村ほか,1991）にも関わらず，その 分布域に地すべり地形は判読されていない。こうした石 見層群と出雲層群の地形の違いは岩盤性状の違いに原因 していると考えられるが，出雲層群において地すべり地 形が少ないのは，その分布域が極度に地形の開析が進ん だ宍道湖周辺域の丘陵地であることに原因している。特 に，布志名層は切土や盛土を伴った地形の改変により小 規模な地すべり・崩壊を発生しやすいが，その分布域に は自然発生的な大規模地すべりを形成するほどの山地が ほとんどないため地すべり地形が判読されていない。

\section{3 斜面の傾斜方位と最頻傾斜角}

図一 6 に各地層の自然斜面の傾斜方位別面積割合を示

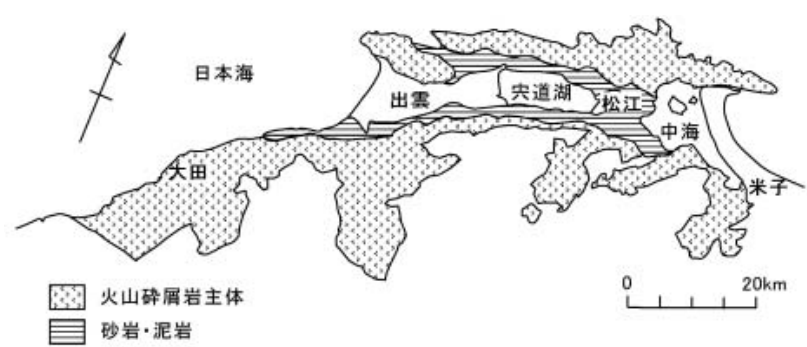

図－3 島根県東部の第三紀層の分布（島根県，1985）

Fig. 3 Tertiary Formation in the Eastern Part of Shimane Prefecture

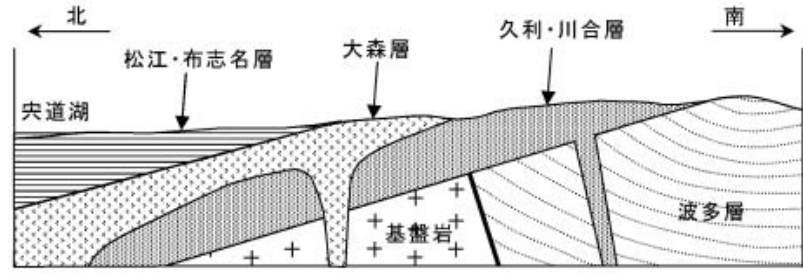

図-4 第三紀層の地質構造

( 5 万分の 1 地質図幅「松江」を参考に著者作成)

Fig. 4 Geological Section of Tertiary Formation in the Eastern Part of Shimane Prefecture

表一 1 島根県東部本土側に分布する第三紀層の構成

Table 1 Stratigraphy of Tertiary Formation (Landside) in the Eastern Part of Shimane Prefecture

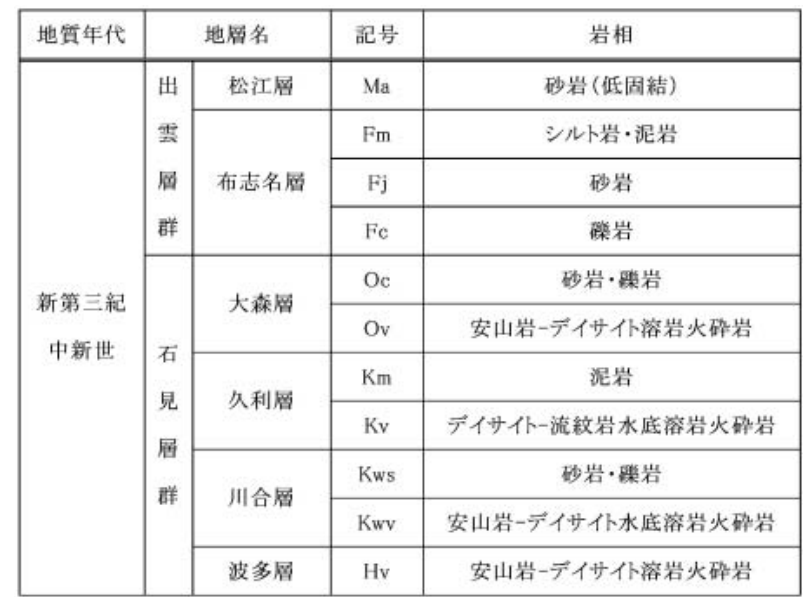




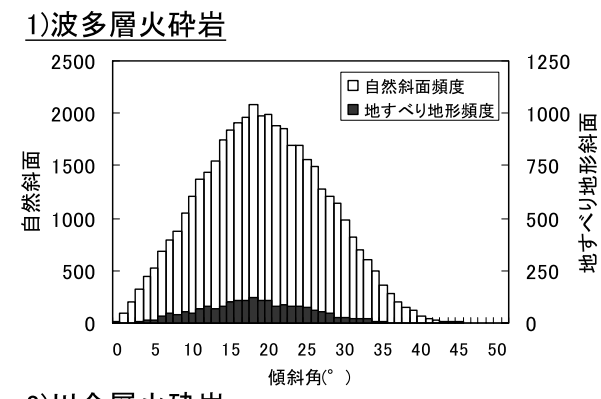

2)川合層火砕岩

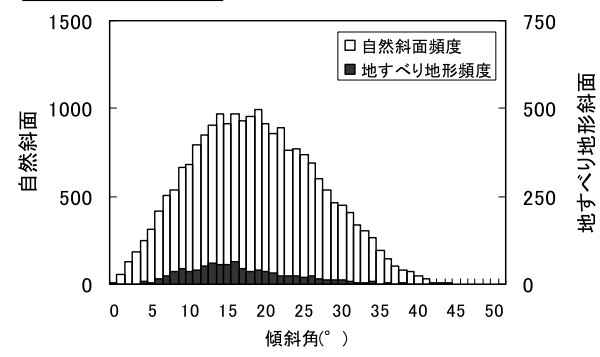

3)川合層砂岩

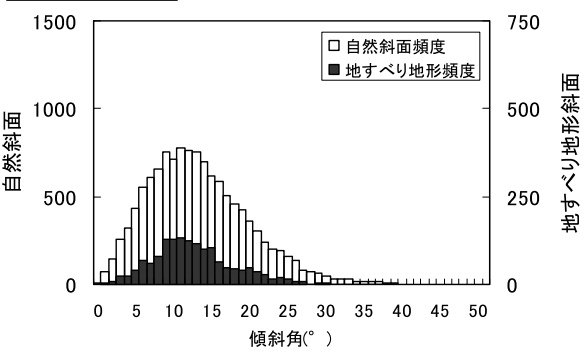

4)久利層火砕岩

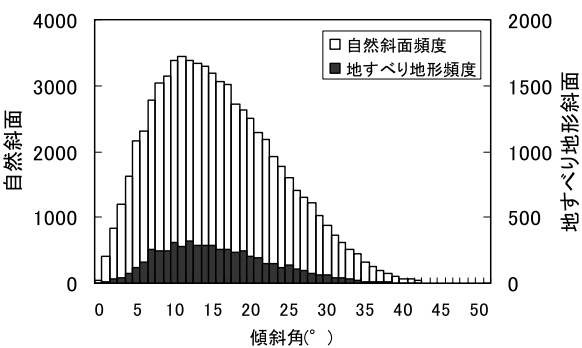

5)久利層泥岩

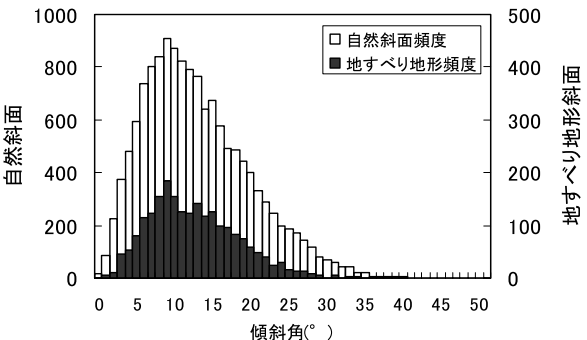

\section{6)大森層火砕岩}

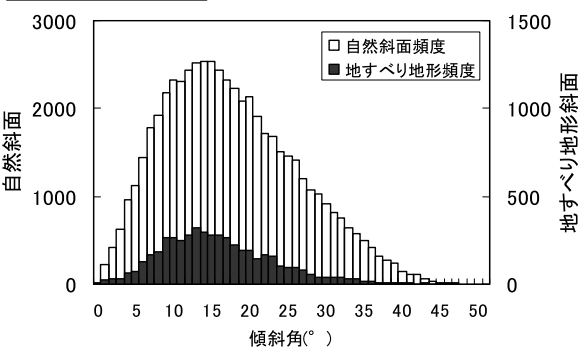

7)大森層碟岩

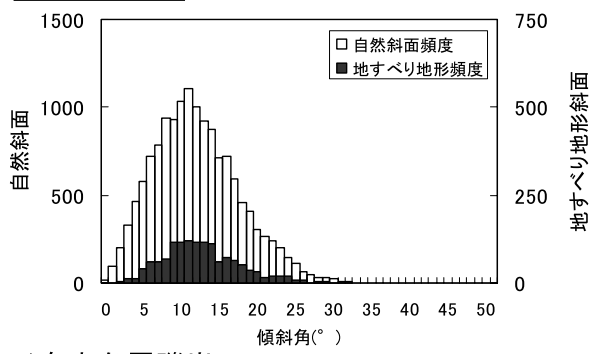

8)布志名層礫岩

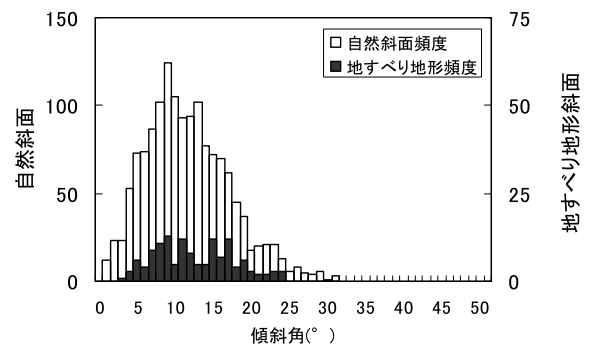

9)布志名層砂岩

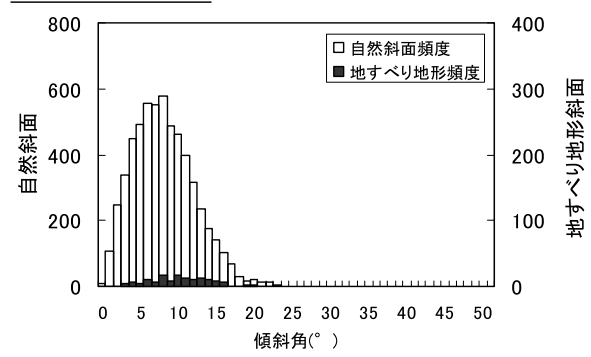

10)布志名層泥岩

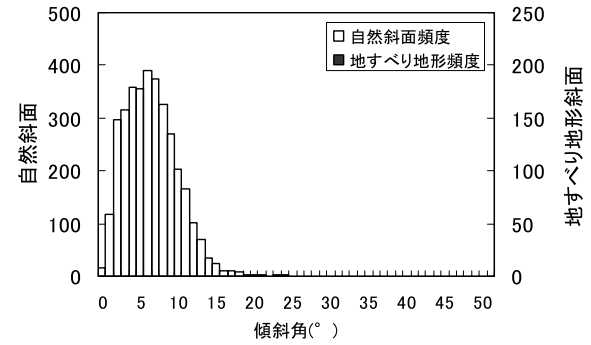

11)松江層砂岩

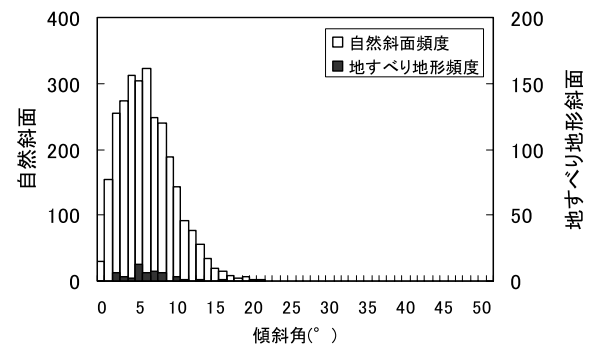

図一 5 自然斜面および地すべり地形斜面の傾斜角の頻度分布図

Fig. 5 Frequency of Angle of Natural Slope and Landslide 
表一 2 自然斜面および地すべり地形斜面の面積割合と最頻傾斜角

Table 2 Area Ratio of Landslide Area and Natural Slope Area to Total Area and the Most Frequent Angle of Slope

\begin{tabular}{|c|c|c|c|c|c|c|c|c|c|}
\hline \multirow{2}{*}{\multicolumn{2}{|c|}{ 地層名 }} & \multirow{3}{*}{ 岩相 } & \multirow{3}{*}{$\begin{array}{l}\text { 記号 } \\
\mathrm{Ma} \\
\end{array}$} & \multicolumn{3}{|c|}{ 自然斜面 } & \multicolumn{3}{|c|}{ 地与バり地形斜面 } \\
\hline & & & & \multirow{2}{*}{$\begin{array}{c}\text { デー夕数 } \\
2792\end{array}$} & \multirow{2}{*}{ 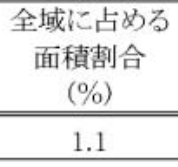 } & \multirow{2}{*}{$\begin{array}{c}\text { 最頻傾斜角 } \\
\text { ( ) }\end{array}$} & \multirow{2}{*}{$\begin{array}{c}\text { デー夕数 } \\
49\end{array}$} & \multirow{2}{*}{$\begin{array}{c}\text { 地層に占める } \\
\begin{array}{c}\text { 面積割合 } \\
(\%)\end{array} \\
1.8 \\
\end{array}$} & \multirow{2}{*}{$\begin{array}{c}\begin{array}{c}\text { 最頻傾斜角 } \\
(\text { ( ) }\end{array} \\
6.0 \\
\end{array}$} \\
\hline 出 & 松江層 & & & & & & & & \\
\hline 雲 & \multirow{3}{*}{ 布志名層 } & 泥岩 & $\mathrm{Fm}$ & 3462 & 1.4 & 6.0 & 0 & 0 & - \\
\hline 層 & & 砂岩 & $\mathrm{Fj}$ & 5824 & 2.4 & 7.0 & 143 & 2.5 & 10.5 \\
\hline 群 & & 磪岩 & $\mathrm{Fc}$ & 1454 & 0.6 & 11.0 & 136 & 9.4 & 12.5 \\
\hline \multirow{7}{*}{$\begin{array}{l}\text { 石 } \\
\text { 見 } \\
\text { 層 } \\
\text { 群 }\end{array}$} & \multirow{2}{*}{ 大森層 } & 磼岩 & $\mathrm{Oc}$ & 14389 & 5.9 & 11.5 & 1398 & 9.7 & 12.5 \\
\hline & & 火研岩 & Ov & 55561 & 22.7 & 15.0 & 5037 & 9.1 & 14.5 \\
\hline & \multirow{2}{*}{ 久利層 } & 泥岩 & $\mathrm{Km}$ & 14088 & 5.8 & 10.5 & 2189 & 15.5 & 11.5 \\
\hline & & 火砕岩 & $\mathrm{Kv}$ & 70578 & 28.8 & 13.5 & 5512 & 7.8 & 14.0 \\
\hline & \multirow{2}{*}{ 川合層 } & 砂岩 & Kws & 12140 & 5.0 & 12.5 & 1551 & 12.8 & 12.5 \\
\hline & & 火砕岩 & Kwv & 21697 & 8.9 & 18.0 & 905 & 4.2 & 15.0 \\
\hline & 波多層 & 火砕岩 & $\mathrm{Hv}$ & 42729 & 17.5 & 20.0 & 1912 & 4.5 & 18.5 \\
\hline
\end{tabular}

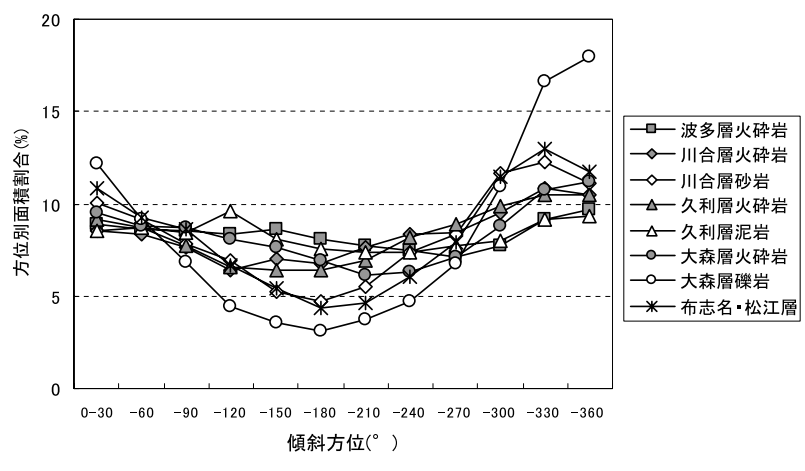

図一 6 自然斜面の方位別面積割合

Fig. 6 Area Ratio of Natural Slope to Total Area in Various Directions

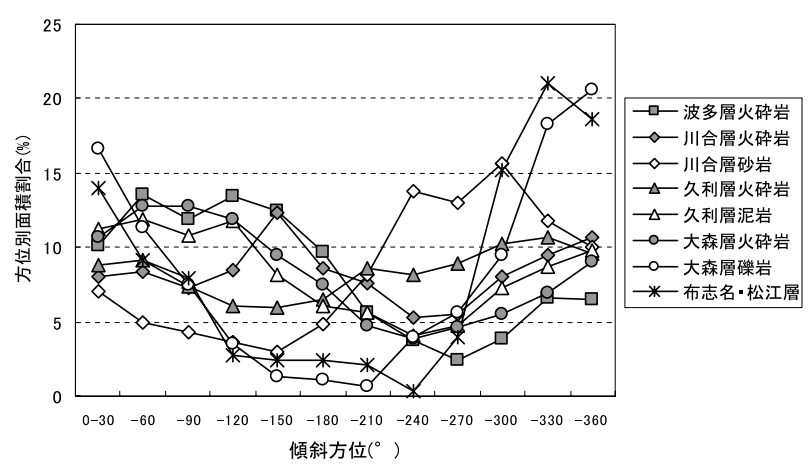

\section{図－７＼cjkstart地すべり地形斜面の方位別面積割合}

Fig. 7 Area Ratio of Landslide to Total Area in Various Directions

す。また，図一7に地すべり地形斜面の傾斜方位別面積

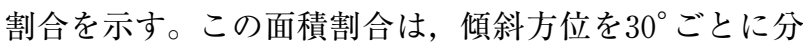
割した際の，その傾斜方位にある斜面の面積の構成割合 である。これによれば自然斜面は全体的に南向き斜面に 比べて北向き斜面が多い様子が見てとれ，地すべり地形 斜面についても同様の傾向が認められる。特に大森層礫 岩と布志名・松江層における地すべり地形斜面は流れ盤

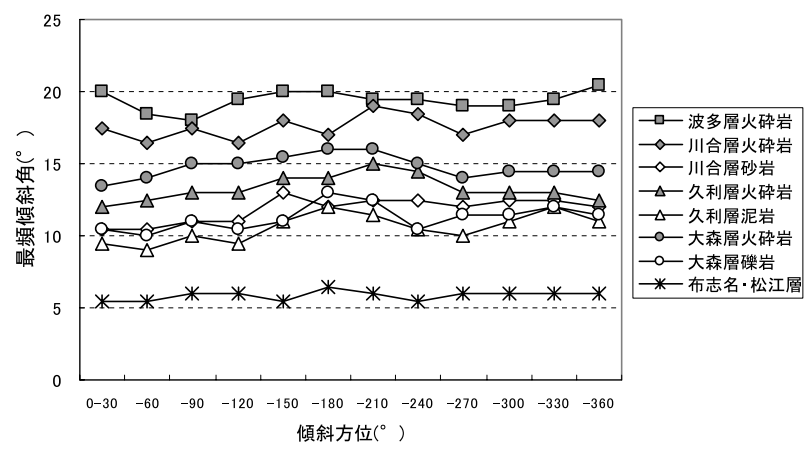

図一 8 自然斜面の方位別最頻傾斜角

Fig. 8 The Most Frequent Angle of Natural Slope in Various Directions

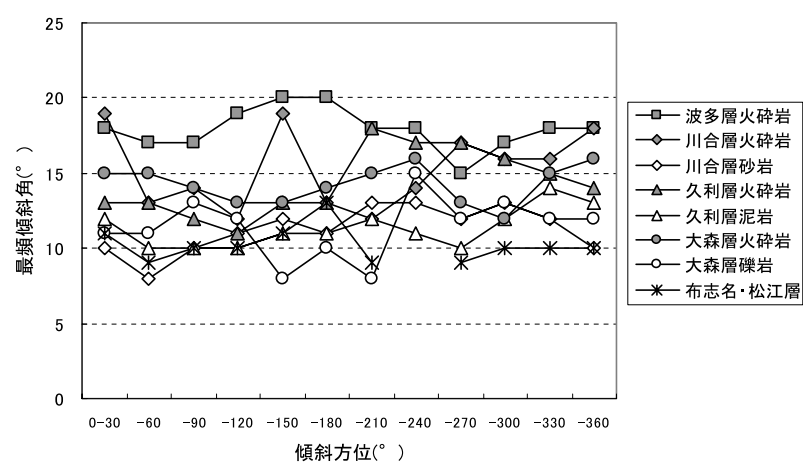

図一9地すべり地形斜面の方位別最頻傾斜角

Fig. 9 The Most Frequent Angle of Landslide in Various Directions

に規制されて北向き斜面が卓越していることがわかる。

一方，図一 8 に各地層の自然斜面の方位別最頻傾斜角 を示し，図一 9 に地すべり地形斜面の方位別最頻傾斜角 を示す。これらによると自然斜面の最頻傾斜角は傾斜方 位による違いがほとんどなく，地すべり地形斜面につい ても，多少のばらつきはあるものの自然斜面と同様の傾 向を示すことがわかる。 


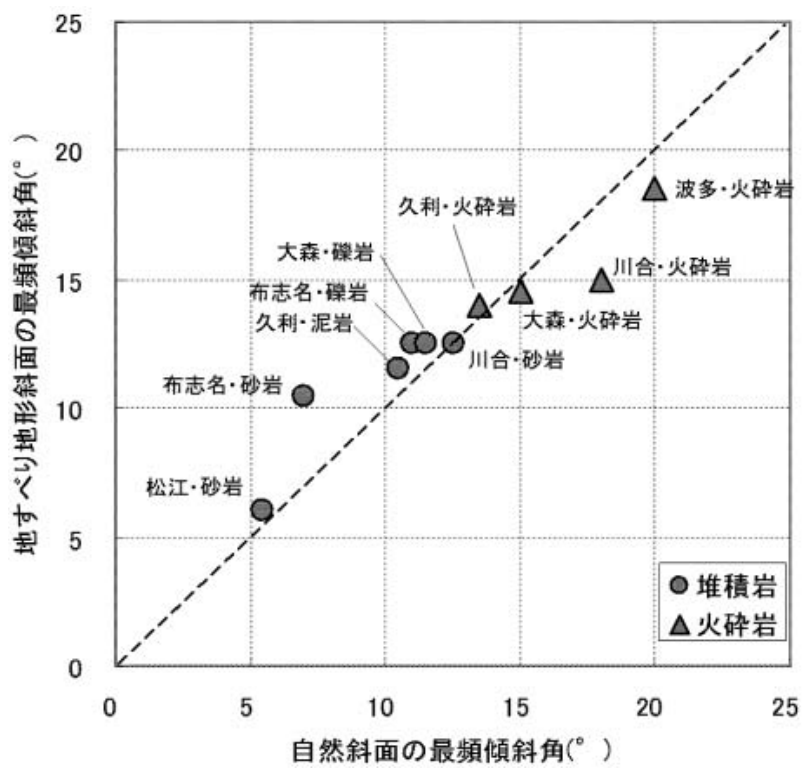

図一10 自然斜面と地すべり地形斜面の最頻傾斜角の対比

Fig. 10 Relationship between The Most Frequent Angle of Landslide Area and Its Belonged Stratum

図-10は各地層の自然斜面と地すべり地形斜面の最頻 傾斜角を対比したものである。火砕岩では自然斜面の方 が若干大きく，堆積岩では地すべり地形斜面の方が若干 大きい傾向が認められるが，両者の違いは数度以内で あってほぼ等しいと見なすことができる。

\section{4. 地すべり地形斜面の最頻傾斜角の工学的特性}

図一11は地すべり地形斜面の最頻傾斜角を層序順に整 理したものである。石見層群の火砕岩では波多層から大 森層に向けて層序が上位になるに従い最頻傾斜角が小さ くなる関係が認められ，また，出雲層群の堆積岩でも同 様の関係が認められる。石見層群の堆積岩ではそうした 関係は認められず， $11.5^{\circ} \sim 12.5^{\circ}$ の範囲でほぼ一定して いるが，全体傾向からすれば層序が上位になるに従って 地すべり地形斜面の最頻傾斜角が小さくなる傾向を認め ることができる。

一方，図-12は各地層の地すべり地形斜面の最頻傾斜 角と自然斜面に占める地すべり地形斜面の面積割合の関 係を示したものである。この関係では，出雲層群を除き， 石見層群の各地層においては最頻傾斜角が小さいほど地 すべり地形の面積割合が大きくなる関倸が認められる。 出雲層群は地形の開析が進んだ丘陵地に分布しているこ とから石見層群とは関係を異にするものと考えられる。

これらのことから，地すべり地形斜面の最頻傾斜角は 地層ごとに違いがあり，石見層群に限れば地すべり地形 の多寡と関係のある地形指標であると言える。地すべり 地形斜面の最頻傾斜角は，はじめにで述べたように，地 すべり面のせん断抵抗角と強い相関があることが明らか にされており，本研究対象域においては，地すべり対策 における地すべり面のせん断抵抗角の推定等において研 究結果を参考にできると考えられる。

\section{5. まとめ}

地すべり地形斜面の最頻傾斜角に着目し, 島根県東部 の日本海沿岸に分布する第三紀層を対象とした $50 \mathrm{~m}$ DEM地形解析を行った。その結果, 本研究対象域にお いては次のことが明らかとなった。

(1) 自然斜面は北向きに傾斜するものが多く，地すべ り地形斜面も北にゆるく傾斜する同斜構造を反映して北 向きに傾斜するものが多いが，自然斜面，地すべり地形 斜面ともに最頻傾斜角には傾斜方位による違いが認めら れない。

（2）地すべり地形斜面の最頻傾斜角は，自然斜面の最 頻傾斜角に比べて火砕岩では若干小さめ，堆積岩では若 干大きめの值を示すものの，ほぼ等しいとみなせる。

（3）地すべり地形斜面の最頻傾斜角は，層序が上位に

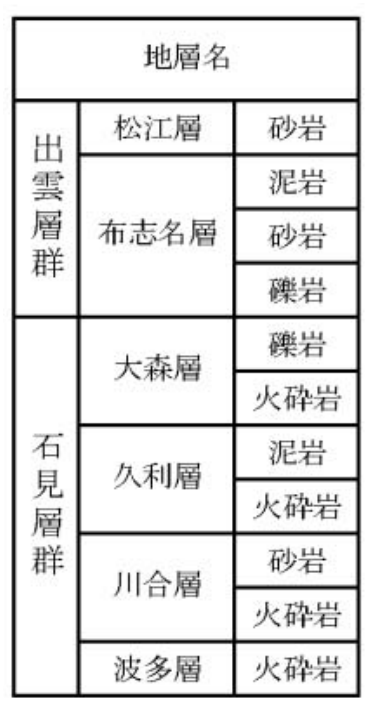

地すべり地形斜面の最頻傾斜角 $\left({ }^{\circ}\right)$

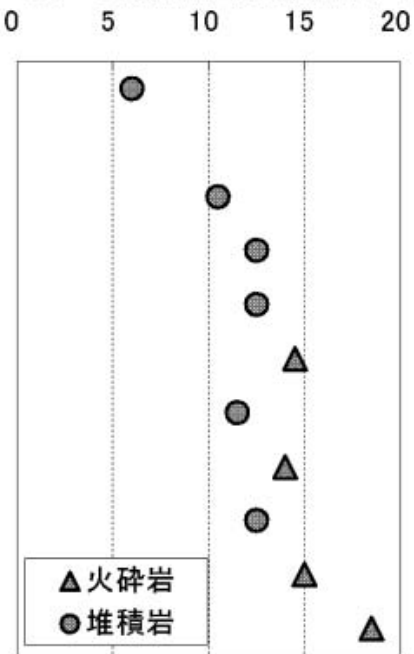

図一11 各層の地すべり地形斜面の最頻傾斜角

Fig. 11 The Most Frequent Angle of Landslide of Each Formation

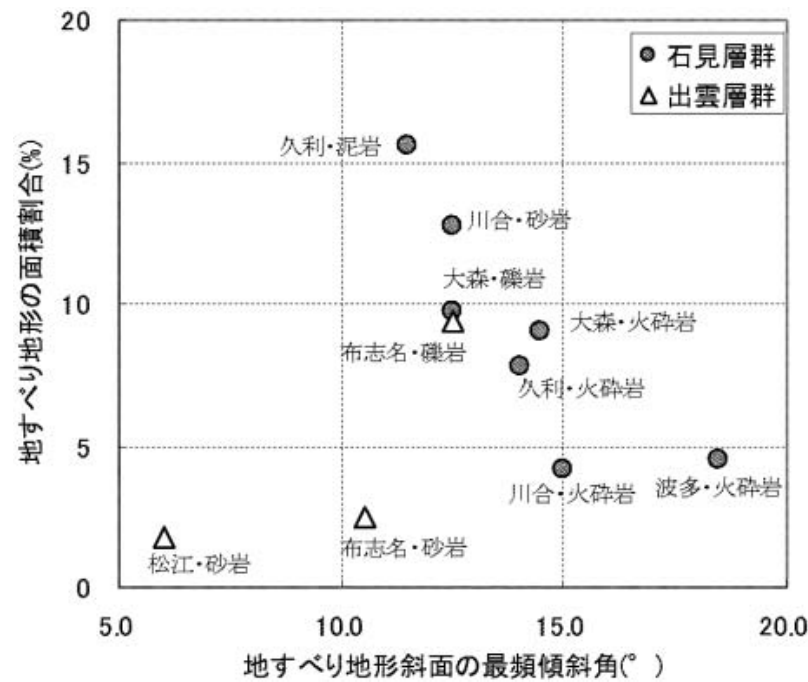

図一12 第三紀層地帯における地すべり地形斜面の最頻傾斜 角と地すべり地形の面積割合の関係

Fig. 12 Relationships between the Most Frequent Angle and Area Ratio of Landslide of Tertiary Formation 
なるに従って小さくなる傾向を示す。また，石見層群で は地すべり地形斜面の最頻傾斜角が小さいほど地すべり 地形の面積割合が大きい関倸が認められる。

\section{謝辞}

本研究の共同著者である山本哲朗氏が，研究途中の 2009年 3 月にお亡くなりになりました。氏のご尽力がな ければ本稿はなかったものと思います。ここに謝意を表 し、ご冥福を扔祈りします。

\section{引用文献}

太田岳洋・八戸昭一 (2006)：数值標高モデルによる地形計測の現 状と応用例，応用地質，Vol. 46, No. 6, pp. 347-360.

岩橋純子・山岸宏光・神谷泉・佐藤浩（2008）：2004年 7 月新潟県 中越地震による斜面崩壊の判別分析, 地すべり, Vol. 45, No. 1, pp. $1-12$.

高速道路調查会（1985）：地すべり地形の安定度評価に関する研究 報告書.

吉松弘行 - 丸山清輝 - 檜垣大介 ・ 綱木亮介 - 吉田克美 (1991)：地 すべり面の土質定数の決定手法, 土木技術資料, Vol. 33，No. 4, pp. $69-75$.

長嶺元二・山本哲朗・大坂伊作（2009）：DEM地形解析による山 口県下の三郡変成岩類からなる地すべり斜面の強度推定，地 すべり, Vol.46, No.3, pp. 43-48.
国土地理院（2000）: 数值地図 $50 \mathrm{~m}$ メッシュ（標高）日本 - III. 沖村孝・吉永秀一郎 - 鳥井良一（1991）：地形特性值と地形区分, 表土層厚の関係－仙台入菅谷地区を例としてー，土地造成工 学研究施設報告, Vol. 9, pp. 19-39.

神谷泉・黒木貴一・田中耕平（2000）: 傾斜量図を用いた地形・地 質の判読，情報地質，Vol.11，No.1，pp. 11-24.

地質調查所（1994）：5 万分の 1 地質図幅「松江」. 地質調查所 (1991）：5 万分の 1 地質図幅「今市」. 産業技術総合研究所 (2005)：5 万分の 1 地質図幅「木次」. 地質調査所（1989）：5 万分の 1 地質図幅「大社」.

地質調查所（1998）：5 万分の 1 地質図幅「石見大田及び大浦」. 地質調査所 (1983)：5 万分の 1 地質図幅「三瓶山」. 地質調査所 (2001)：5 万分の 1 地質図幅「温泉津及び江津」. 鹿野和彦 - 山内靖喜 - 高安克己 - 松浦浩久 - 豊遙秋 (1994)：松江 地域の地質，地域地質研究報告，p. 99 .

松浦浩久 - 鹿野和彦・石塚吉浩・高木哲一（2005）：木次地域の地 質, 地域地質研究報告, p. 31 .

防災科学技術研究所（2005）：地すべり地形分布図，第278号，「松 江」,「横田」,「多里」.

防災科学技術研究所 (2006)：地すべり地形分布図, 第285号,「今 市」,「木次」,「頓原」，「大社」，「石見大田」，「三瓶山」，「大 浦」, 「温泉津」.

島根県（1985）：島根県の地質，p. 24 .

三浦清（1982）：島根県下の地すべり－泥岩の岩質との関係一，第 21回日本地すべり学会研究発表会論文集, pp. 110-111.

中村康夫・平野勇・佐々木靖人・阿部正彦（1991）：軟岩切土のり 面の劣化予測, 土木研究所資料, No. 2930.

（原稿受付2008年 5 月 29日，原稿受理2009年 6 月29日） 